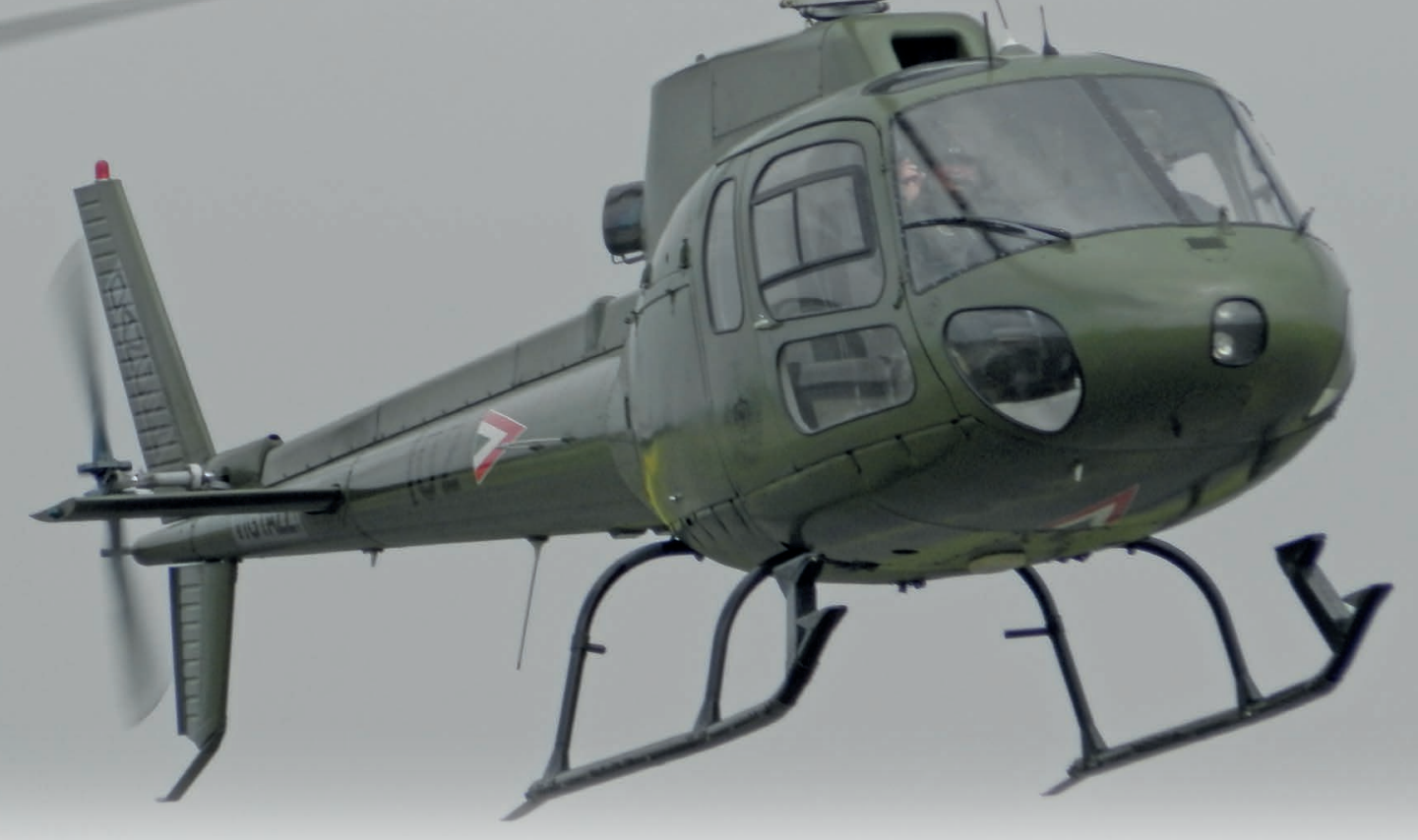

Hegyi Imre* - Kelecsényi István**

\title{
A levegő „Mókusa”, az AS 350-355 könnyúhelikopter-család
}

\section{ELŐTÖRTÉNET}

Az 1970-es évek végén az Aérospatiale az elavuló Alouette helikoptercsalád pótlására új könnyűhelikopter-programot indított. Az Alouette II (Pacsirta) SE 3130/313B típusjelzésű helikopterek az 1950-es évektől kezdődően az Aérospatiale elődje, a Sud Aviation cég által tervezett többcélú könnyű helikopterek voltak. A Pacsirtát katonai és polgári alkalma- zásra egyaránt használták, és a II. változatból 1305 db-ot, a III. (AS 316) változatból 1453 db-ot gyártottak. Franciaországon kívül India HAL SA 315B Lama, illetve Chetak, Románia IAR 316/317 néven további példányokat állított elő.

A helikopterek elterjedése a haderőkben és más fegyveres testületeknél felgyorsította a fejlesztéseket. Az Alouette család harci alkalmazásra az 1970-es évektől már kevéssé volt alkalmas. Ennek ellenére megbízható forgószárnyas-
ÖSSZEFOGLALÁS: A francia Aérospatiale cég által fejlesztett AS 350 könnyühelikopter-családot napjainkban már az Airbus Helicopters gyártja, polgári $H$ 125 (AS 350 B3e) és katonai H 125 M (AS 550 C3e) típusjelzéssel. 1991-ben az Országos Mentőszolgálat (OMSZ) egy, majd ezt követően még kettő darab AS 350 B Écureuilt (Mókus) rendszeresített, ezek voltak az első nyugati gyártmányú mentőhelikopterek hazánkban. Az OMSZ intenzíven, 23 éven keresztül használta a helikoptereket. A típus megbízhatóságának és magas színvonalú karbantartási háttérnek köszönhetően 2016-ban 2 db-ot kiváló állapotban vett át a Magyar Honvédség. Ezek a könnyü helikopterek katonai pilótaképzést, megfigyelést, teheremelési feladatokat hajtanak végre.

KULCSSZAVAK: Sud Aviation, Aérospatiale, könnyú helikopter, AS 350 Écureuil, Astar, Twinstar, OMSZ, Honvédség, MH 86. Szolnok Helikopterbázis, pilótaképzés, Airbus H 125
ABSTRACT: The AS 350 light helicopter family developed by the French Aérospatiale company is now manufactured by the Airbus Helicopters under H 125 (AS 350 B3e) commercial type name and H 125 M (AS 550 C3e) military type name. In 1991, the Emergency Medical Service (EMS) entered into service one and then two AS 350 B Écureuilt (Squirrel) helicopters; in Hungary, these were the first rescue helicopters made in the West. The EMS has used helicopters intensively for 23 years. Due to the reliability of the variant and high-quality maintenance background, the Hungarian Defence Forces received 2 units in excellent condition in 2016. These light helicopters carry out military pilot training, observation, lifting tasks.

KEY WORDS: Sud Aviation, Aérospatiale, light helicopter, AS 350 Écureuil, Astar, Twinstar, EMS, Hungarian Defence Forces, HDF 86th Szolnok Helicopter Base, pilot training, Airbus $\mathrm{H} 125$

\footnotetext{
* ORCID: 0000-0002-3705-5713
}

** ORCID: 0000-0001-5563-3313 


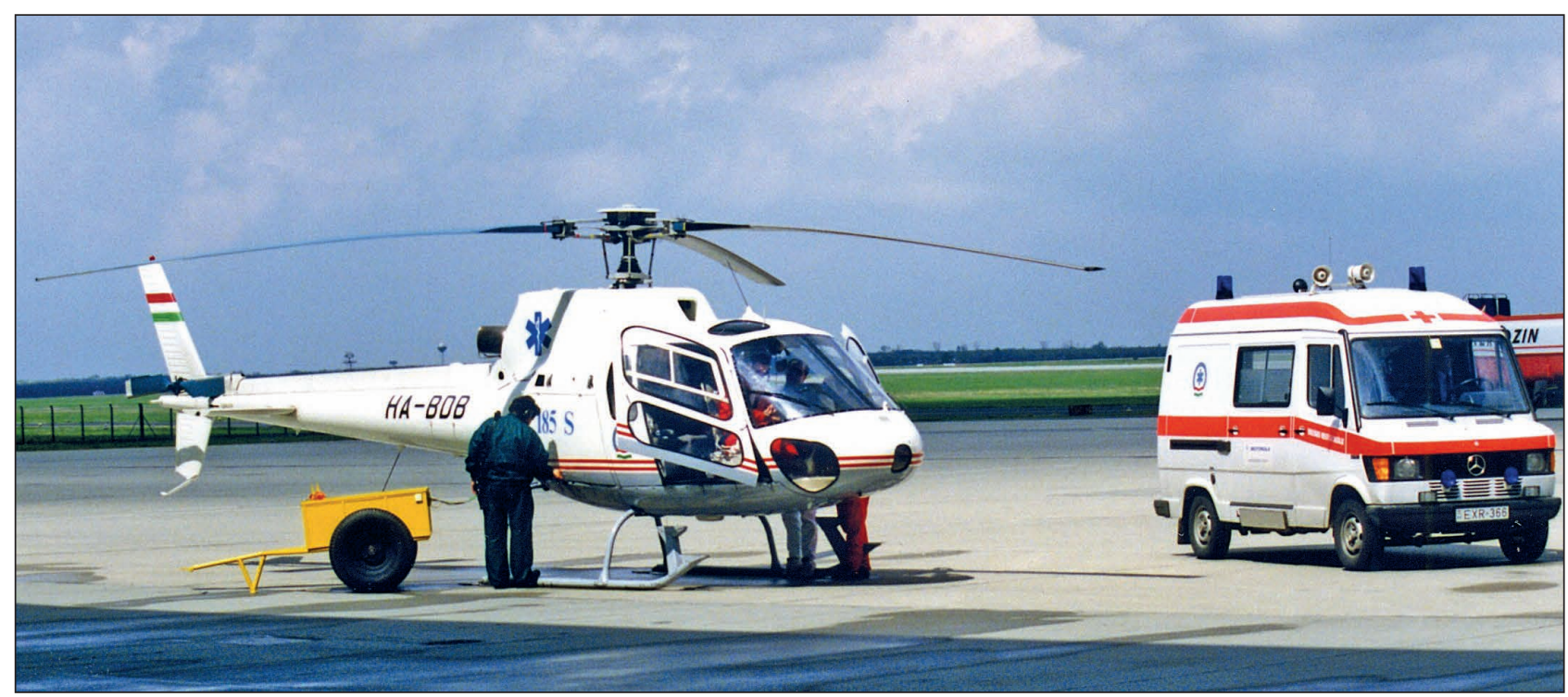

2. ábra. 1991-ben az Országos Mentőszolgálat (OMSZ) 3 db AS 350 B Écureuilt rendszeresített, ezek voltak az első nyugati gyártmányú mentőhelikopterek hazánkban. A képen az eredeti színekben, civil lajstrommal, valamikor a kilencvenes évek elején, a Ferihegyi repülőtéren (Fotó: Zainkó Géza gyűjteményéből)

nak bizonyult, és - többségében kiképző és mentőhelikopterként - a mai napig több országban rendszerben áll.

Az Egyesült Királyság és Franciaország közös katonai helikopter-fejlesztésbe kezdett, a Westland Helicopters és a Sud Aviation közreműködésével. 1967. április 7-én emelkedett fel az első prototípus, majd több előtanulmány és kísérleti változat után elkészült az SA 341 Gazelle. Bár az új helikopter a Pacsirta katonai utódja lett, de új tervezésű volt, modernebb, karcsúbb és áramvonalasabb kialakítású. Forradalmi újításként házba épített, úgynevezett fenestron rendszerű faroklégcsavarral szerelték fel. Ez volt az első ilyen kialakítású helikopter. A fejlesztők több alváltozatot alakítottak ki, könnyű felderítő és futár, valamint felfegyverzett modifikációk könnyű támogató és páncéltörő feladatkörökre. Utóbbiakat például az öbölháború során is sikeresen vetették be.

Polgári változatokat is készítettek belőle. A britek és franciák összesen 1250 db-ot gyártottak, de a jugoszláviai SOKO repülőgépgyár $S A 314 \mathrm{H} / \mathrm{L}$ és $342 \mathrm{~L}$ változatokat is gyártott 1991-ig. Utóbbiból több mint egy tucat példány került Magyarországra, ahol egy Várpalotához közeli telephelyű cégnél karbantartást és kisebb átalakításokat is végeztek, majd a forgószárnyasok egy része külföldön talált új gazdára, de jónéhány magyar lajstromban repül még napjainkban is.

\section{Az AS 350 B ÉCuREUIL fEJLESZTÉSE}

A René Mouille vezette tervezőcsapatnak egy gazdaságos üzemeltetésű, egyszerű kezelésű és a Gazelle-nél olcsóbb, új forgószárny-rendszerrel felszerelt helikopter fejlesztése volt a célja, elsősorban polgári célokra, de a terv végül a katonai követelményrendszernek is megfelelt. A Gazelle kora legkorszerübb könnyü helikopterének számított, de innovatív újításai - például a fenestron rendszerű házba épített faroklégcsavar - miatt beszerzési ára magas volt, ami gátolta széles körű elterjedését. A konvencionálisabb tervezésű AS 350-es helikopter olcsóbb alternatívát kínált a civil felhasználók részére is. Az első prototípus, amelyet az amerikai gyártmányú, 460 kW (625 LE) tengelyteljesítményű Lycoming LTS 101 hajtóművel szereltek fel, SA 350 típusjelzéssel (F-WVKH) 1974. június 27-én repült előszőr
Marignane-ban. A második prototípus már az erősebb, francia gyártmányú Turbomeca Arriel $1 \mathrm{~A}$ típusú gázturbinás hajtóművet kapta meg, és az első repülésre 1975. február 14-én került sor. A helikoptert gyártó cég nevére (Sud Aviation) utal a helikopterek típusjelzésében található első két betű, az SA. Ezt a későbbiekben AS-re módosítják, mivel a Sud Aviation cég átalakulását követően a cég az Aérospatiale nevet kapja. A gyártó csak az amerikai piacon forgalmazta a Lycoming LTS 101 hajtóműves típust, a világ többi részén a gépet a nagyobb tengelyteljesítményű Turbomeca Arriel 1-es gázturbinával kínálta.

A helikopter a típusbizonyítványt a francia légügyi hatóságtól (DGCA) 1974-ben kapta meg, amely alapján a sorozatgyártását 1978 márciusában AS 350 B Écureuil (Mókus) típusjelzéssel kezdték meg Marignane-ban. Az Egyesült Államokban áprilistól kezdték az AS 350 C AStar típusjel-

3. ábra. Az OMSZ kötelékében szolgáló AS 350 B Écureuilök, idővel az Európai Unióban is alkalmazott, mentőhelikopterekre jellemző rikító sárga festést kaptak, amikor a

honvédség kötelekébe kerültek, egy ideig megtartották ezt a színt, ami igencsak bizarr külsőt kölcsönzött az ék alakú felségjellel és a szolnoki alakulat emblémájával (Fotó: Kelecsényi István)

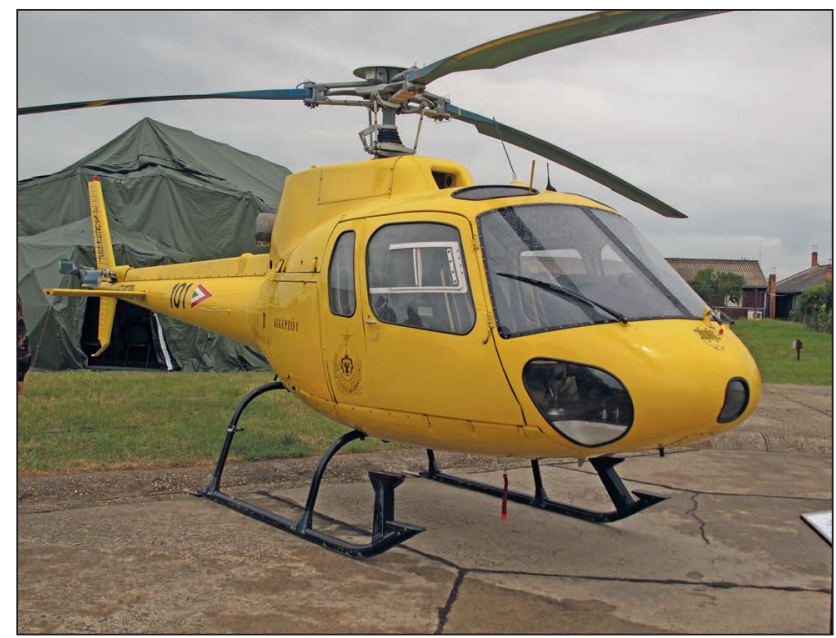


zésű, Lycoming LTS 101-es hajtóművel felszerelt típus forgalmazását.

A helikopter fejlesztése a sorozatgyártás megkezdése után is tovább folytatódott. A forgószárny-rendszer, hajtómű, avionikai berendezések cseréjével újabb változatokat készítettek. Az olcsó üzemeltetés alternatíváját jelentő hagyományos felépítést egy prototípus erejéig majdnem „megcáfolta” az Aérospatiale, amikor 1987. február 6-án faroklégcsavar helyett Fenestron csőlégcsavart épített egy AS 350 B2-es helikopterbe, amely az AS 350 Z típusjelzést kapta. A tervet végül elvetették, és a hagyományos elrendezésű Écureuil maradt sorozatgyártásban, azonban a házba épített faroklégcsavarral szerzett tapasztalatok nem vesztek kárba, mert azokat felhasználták az EC 120 Colibri és az AS 350 B4 (EC 130) tervezésénél. Az erősebb, 480 kW (653 LE) teljesítményű Arriel 2B hajtóművel készített $A S$ 350 B3 prototípus 1997. március 1-jén repült először. A helikopterekbe egyre több digitális rendszert, többek között avionikai műszereket, Garmin $\mathrm{G} 500 \mathrm{H}$ müholdas navigációt, EECU hajtóművezérlő-rendszert építettek be.

A Franciaországban gyártott helikopterek mellett, 2013ban elindult a gyártás az USA-ban, a Mississippi állambeli Colombus városában is. A 2015 decemberében összeszerelt AS 350 B3e megkapta az amerikai Nemzeti Légügyi Hatóság (Federal Aviation Administration - FAA) tanúsítványát is. A gyár évente 65 db helikopter előálítására képes.

\section{A HELIKOPTER MŰSZAKI FELÉPITTÉSE}

Az AS 350 egyhajtóműves könnyű helikoptert háromlapátos forgószárnnyal és kétágú faroklégcsavarral szerelték fel. A forgószárnylapátok, a faroklégcsavar és a forgószárnyagy központi csillag alakú Starflex elemét is üvegszál erősítésű kompozit anyagból alakították ki, ezzel a hagyományos korróziós problémákat sikerült a minimálisra csökkenteni. Az új fejlesztésű, csukló és csapágy nélküli, Starflex rendszerü forgószárny-rendszernek köszönhető az alacsony karbantartási igény is, mivel az egész rendszerben csak egyetlenegy helyen alakítottak ki zsírzási pontot. A helikopterben lévő vibrációs szint az új fejlesztésű forgószárny-rendszernek, az ahhoz kapcsolódó főreduktor vibráció-elnyelő bekötéseknek, valamint az utaskabin alatt található vibráció-csillapító elemeknek köszönhetően nagyon alacsony. A típusra jellemző a hajtómű gyors indíthatósága, ami alkalmassá teszi készenléti szolgálati (például mentő vagy rendőrségi feladatkörben) használatra. Az avionika nagy része - többek között a rádió- és műholdas navigációs és kommunikációs berendezések - a Garmin és Bendix King cégektől származik. Az újabb változatokba már folyadékkristályos kijelzők és digitális avionikai felszerelést építettek be. Az új fejlesztésű VEMD-rendszer (Vehicle and Engine Management Display) leváltotta a hagyományos analóg műszereket. A helikopterkonfigurációtól függően 4-6 fős maximális utaslétszámra kialakított belső térrel rendelkezik, a felszerelések és a belső tér berendezése is rugalmasan változtatható az igények szerint. A fegyveres testületek részére beépíthetők infravörös kamerák (FLIR), külső tükrök, taktikai konzolok, kabinpadló ablak, valamint speciális emelő- és csörlőberendezések. Továbbá biztosíthatók a valós idejű adatkapcsolatok és az éjjellátó képesség is. A hajtómű szívócsatornája elé opcionálisan felépíthetők porkiválasztó, illetve -szűrő elemek, amelyek megakadályozzák a hajtómű-kompresszorlapátok erózióját. A régebbi változatoknál lehetséges további fejlesztés, amelyet a gyártó a szervízkönyvben szerepeltet.

A helikopterek kiválóan alkalmasak magashegyi környezetben történő repülésre. Az AS 350 B3 változattal Didier
Delsalle tesztpilóta 2005. május 14-én megérintette a 8848 méter magasságú Mount Everest (Csomolungma) csúcsát, amely a Föld legmagasabb pontja. Azóta több, a Himalájában és más magas környezetben dolgozó mentőszolgálat, illetve kereskedelmi repülőtársaság alkalmazza az AS 350es típust.

Licenc alapján, Franciaország és az USA mellett több országban is gyártják ezt a típust, például Brazíliában a Helibras vállalatnál, a saját fegyveres erők számára. A latin-amerikai országban változattól függő, saját típusjelzésekkel közel 350 db-ot készítettek a Mókusból.

2010-től a Helibras modernizálja a katonai változatokat, amelyeket digitális műszerfallal, új kommunikációs és navigációs rendszerrel, páncélzattal és új energiaelnyelő ülésekkel szerel fel. 36 db forgószárnyast építettek így át, az utolsó 2018-ben készült el.

Az Écureuilt Kínában a Shenzeni Airbus Helicopters China (CHAIG) helikoptergyár építi. Az első kínai gyártású változat 1997-ben repült. A sorozatgyártás először az AS 350 B2-vel egyenértékű volt, Arriel 1D hajtóművel, de szélesebb orr-résszel és W8ZD típusjelzéssel. 2003-tól Z-11 MB1 névvel az Arriel 2B1A hajtóműves változatokat gyártják, de saját konfigurációk alapján. A Z-11 sorozat számos polgári és katonai változatban készül, kéthajtóműves változatokat azonban nem gyártanak.

A katonai egyhajtómúves változatokat a kereskedelemben $\mathrm{H}-125 \mathrm{M}$ Fennec típusjelzéssel látják el. Ezek a gépek az Airbus HeliForce moduláris fegyverrendszerrel, infravörös érzékelő toronnyal, lézer célmegjelölővel, sisakra szerelt célzókészülékkel, és a rendszerbe integrált fegyverrendszerekkel egyaránt felszerelhetők.

A tradicionális egyhajtóműves Écureuilnek 30 különböző polgári és katonai változata ismert.

\section{Az EC 130-As változat}

Az Écureuil helikoptercsalád egyik változata az EC 130-as, amely az AS 350 alaphelikopter törzsének kiszélesítése következtében, nagyobb kabinterével 6-7 utas szállítására képes. Fejlesztését 1998-ban végezték, és 1999. június 24-én repült az első prototípusa AS 350 B4 típusjelzéssel. A helikopter meghajtását egy, a kor színvonalának megfelelő, FADEC digitális vezérlésű Turbomeca Arriel 2B1 hajtómű biztosítja, amely $632 \mathrm{~kW}$ (860 LE) teljesítményre képes erőforrás. Forgószárny-rendszere megegyezik az alaphelikopterével, és már a harmadik generációs fenestron farok csőlégcsavarral építik. Jelenleg az Airbus H 130 kereskedelmi típusjelzéssel gyártja, túrarepülésre és medevac mentőfeladatokra ajánlja a rendkívül csendes és alacsony üzemeltetési költségű típust. 2012-ben bemutatták az EC 130 T2-t, amelyet aktív vibrációcsökkentő rendszerrel, modernizált avionikával szereltek, és Arrius 2D hajtóművel, nagyobb felszállósúly és sebesség mellett is alacsonyabb üzemanyag-fogyasztással rendelkezik. 2018-ban az Airbus új változatot alakított ki: az ACH 130-ast VIP szállítóhelikopterként mutatták be.

A H 130 típusokból nem alakítottak ki külön katonai változatot.

\section{Az AS 355-0̈S, KETTŐ HAJTÓMÜVEL ELLÁTOTT VÁLTOZAT}

Az egyhajtóműves AS 350 Écureuil jó alapot adott egy nagyobb terhelhetőségű, kéthajtóműves változat kifejlesztésére. Tervezését 1978-ban kezdték meg, és az első prototípus 1979. szeptember 28-án végrehajtotta a felszállást. 


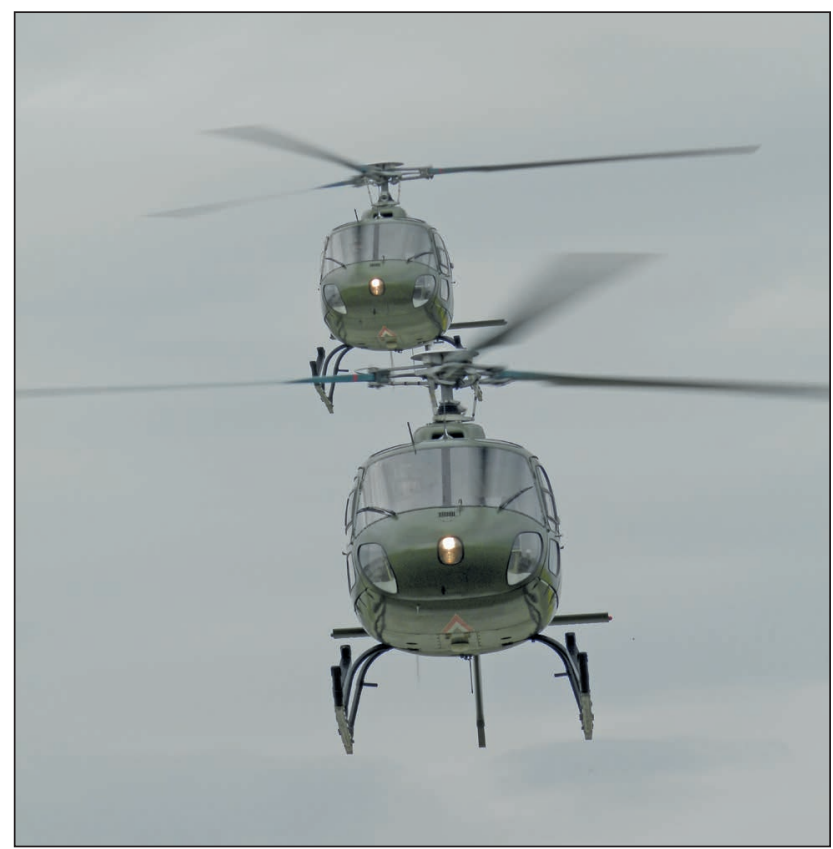

4. ábra. A Magyar Honvédség 2016-ban 2 db, eredetileg az Országos Mentőszolgálat állományában szolgált AS 350 B Écureuil helikoptert vett üzemeltetésbe (Fotó: Baranyai László)

A helikopterekből két prototípus (AS 355 E/F) készült Allison 250 C20 hajtómúvel. A forgószárnyasnak az Aérospatiale az AS 355 típusjelzést és az Écureuil 2 / Twin Squirrel (Iker Mókus) nevet adta. Észak-Amerikában a típusnak a Twinstar (Ikercsillag) nevet adták.

A kéthajtóműves és a CAT A követelményeknek megfelelő típus, az AS 355 F2 / AS 355 NP, olyan területeken is alkalmazható, amely felett az Európai Unió rendelete alapján egyhajtómúves forgószárnyassal nem engedélyezett az üzemelés.
A kéthajtóműves Écureuilnek 12 különböző polgári és katonai változata ismert.

Az AS 355 N és az AS 350 B3 specifikációi közel azonosak, de a kéthajtómúves változat 15\%-kal nagyobb hasznos terheléssel rendelkezik, valamint elsősorban a pogygyásztartó részben találhatók különbségek. A Mókus kéthajtóműves polgári és katonai változatának gyártását 2016 végére megszüntették.

\section{ÜZEMELTETŐK}

Az Écureuilt a különféle polgári, civil üzemeltetők mellett számos ország fegyveres testülete, különféle rendvédelmi szervezetei, rendőrsége, vám- és határőrsége is rendszeresítette.

A Magyar Országos Mentőszolgálat, majd a Magyar Légimentő Nonprofit Kft. 1991 és 2014 között több ezer közúti baleseti, valamint egyéb sérült és beteg életét mentette meg az Écureuil-lel. A Balatonfüreden állomásozó AS 350-es helikopter részt vett többek között a 2010-es „vörösiszap-katasztrófa" mentési munkálataiban is.

Érdekességképpen említendő, hogy a Red Bull csapata a repülőverseny televíziós közvetítéséhez beszerzett egy 2009-ben gyártott AS 350 B3+ gépet.

\section{Az AS 350 B ÉCUREUIL A HONVÉDSÉGBEN}

Az AS 350 B típusjelzésű változatából 1991-ben egyet, majd az azt követő években plusz kettőt szerzett be az Országos Mentőszolgálat légimentés céljára. A HA-BDC lajstromjelű helikopter 2009-ben földi hajtómüpróba során emberi mulasztás miatt felborult, és gazdasági totálkáros lett. A HA-BDA és HA-BDB helikoptereket 2014 novemberében kellett leállítani, mivel az Európai Unió jogszabályai alapján egyhajtóműves típusoknak a polgári üzemeltetésben - repülésbiztonsági okból - nem lehet sűrűn lakott te-

5. ábra. A helikopter kis tömegéhez mért Turbomeca Arriel hajtómú jelentős teljesítményfelesleget biztosít a pilóták manővereihez. A képen dinamikus emelkedés a Tisza partjáról (Fotó: Kelecsényi István)

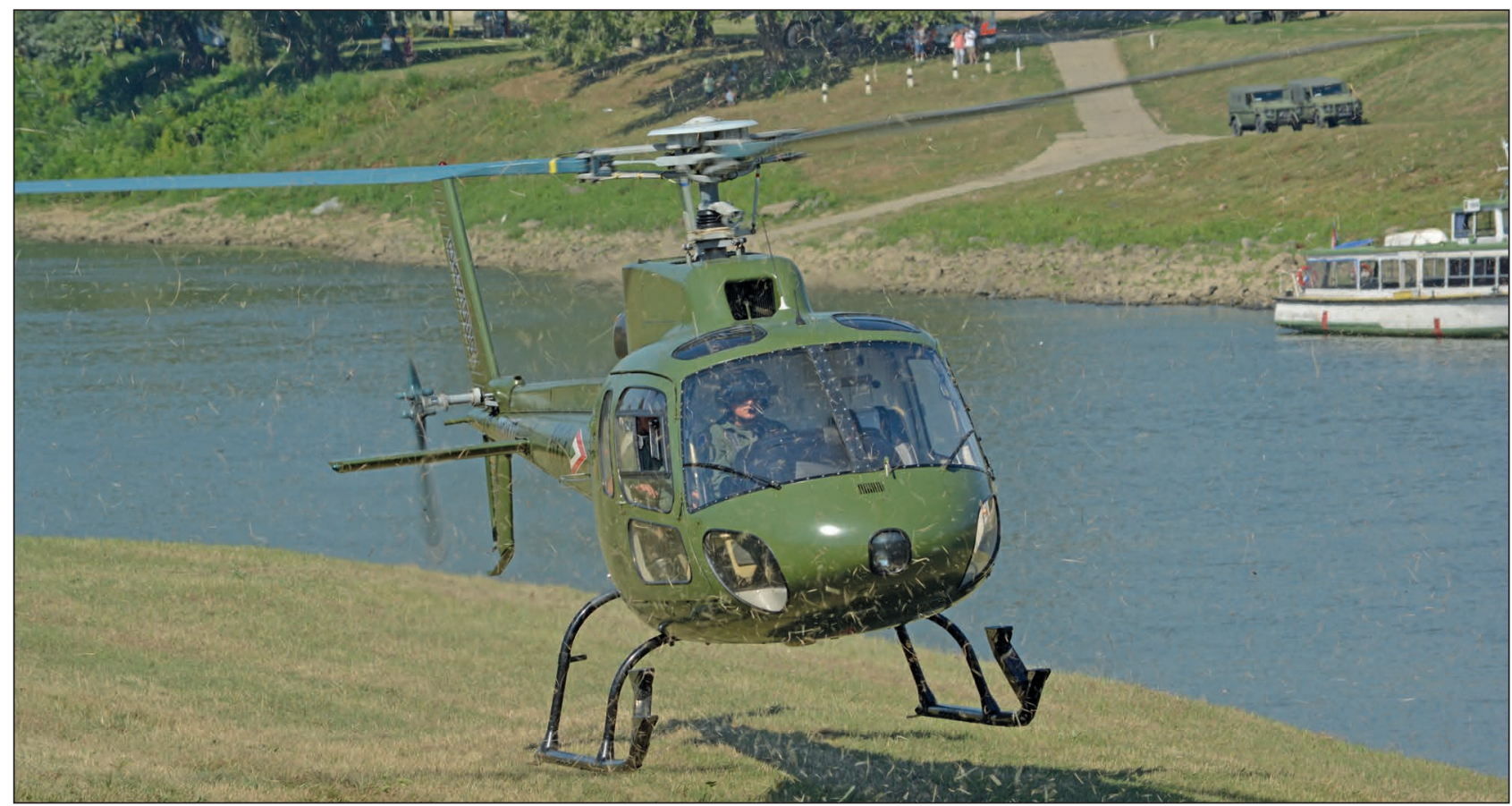


jel-nappal bevethetnek mesterlövészeket, hasonló helikopterekkel.) 2016 májusában már 1300 repült órát teljesítettek a két forgószárnyassal. A hajózók szerint ezekkel a gépekkel nehezebb leszállni, mint a Mi-8-asokkal, mivel nem kerékre, hanem csúszótalpra ereszkednek, amely merev, nincs rugózása. A helikopter össztömege két tonna alatt van, ezért érzékenyebb az oldalszélre, tehát a függeszkedés során az egy helyben tartása nehezebb, mint az orosz típusoknak. Az AS 350 B mindig a jobb csúszótalpról száll fel, amely eltérést a faroklégcsavaron keletkező vonóerő nyomatéka okozza. A forgószárny forgási iránya megegyezik a katonai szállító helikopterekével. A magyar helikopterek nem rendelkeznek robotpilótával. Üzemeltetési költségük a Mi-8/17-nek körülbelül egyhatoda, például 180 I kerozin elegendő egy órányi repülésre, míg a Mi-8T ugyanennyi idő alatt 800 I üzemanyagot fogyaszt. Az AS 350 B nagyjavítási ciklusa 144 hónap. A honvédségnek átadott helikopterek nagyjavítására a HM Védelemgazdasági Hivatala 2017 novemberében írt ki közbeszerzési eljárást, amelyet a magyar HeliControl Kft. nyert el. A cég rendelkezik az EASA Part-145 minőségbiztosítási tanúsítvánnyal. A karbantartás-

6. ábra. A francia mérnökök kiváló munkáját bizonyítja, hogy a „Mókus" helikopterek a föld összes kontinensén repülnek (Fotó: Kelecsényi István)
1. táblázat. Az egyhajtómúves, a honvédségben is alkalmazott $A S 350$ és a kéthajtómúves AS 355 helikopterek fontosabb múszaki adatai

\begin{tabular}{|l|c|c|}
\hline \multirow{2}{*}{ Katonai helikopterek } & AS 350 & AS 355 \\
\cline { 2 - 3 } & Astar & Twinstar \\
\hline Förotorátmérő & \multicolumn{2}{|c|}{$10,69 \mathrm{~m}$} \\
\hline Hosszúság & \multicolumn{2}{|c|}{$10,91 \mathrm{~m}$} \\
\hline Magasság & $3,15 \mathrm{~m}$ \\
\hline
\end{tabular}

Tömegadatok

nyilt a nagyobb és drágábban üzemeltethetô Mi-8T/Mi-17 flotta leváltására. A futár, könnyú teherszállító, felderítő-megfigyelő, határrendészeti és személyszállítási feladatok mellett a hajózó állomány kiválasztási, kiképzési és szinten tartó repüléseire is alkalmazható a típus. A két Écureuil forgószárnyas 2016. június 16-án sárga színben a bázis címerével $\mathrm{KI}$ KÉPZŐ1 és 2 oldalfelirattal az MH 86. Szolnok Helikopterbázison állt szolgálatba 101 és 102 lajstromszámmal. A helikoptereket a Magyar Légimentő Nonprofit Kft. térítésmentesen adta át a honvédségnek. A katonai Mókusok rövid ideig pompáztak sárga színben, mert felsővezetői döntést hoztak a helikopterek katonai színekre történő átfestéséről. Az MH Légijármü Javítóüzeme és a szolnoki karbantartó század közös munkájával Temadur márkájú, kétkomponensű festékkel zöld színre festették át a gépeket. $A z$ átfestés során megközelítőleg $10 \mathrm{~kg}$ festéket használtak el, amit a festést követő súlymérés igazolt. A helikopterek belső átfestésére nem volt szükség, maradt a feketeszürke szín. A festés 7-8 éves időtartamot (közel egy teljes nagyjavítási ciklust) kibír, különösen, ha a helikoptereket fedett helyen tárolják, ahol a légi járműveket nem éri csapadék, fagy és napsugárzás.

2016. október 25-én a 101-es már repült egy Szolnokon rendezett terrorelhárító hadgyakorlaton. Az itt elmondottak alapján ajtólövész alkalmazásával bővült a feladatkör. Hazánk különleges erőinek mesterlövészei akár levegőből is leküzdhetnek célokat a helikopterrel. (Franciaországban a készenléti szolgálatok éj-

\begin{tabular}{|c|c|c|}
\hline \multicolumn{3}{|c|}{ Tömegadatok } \\
\hline Szerkezeti tömeg & $1065 \mathrm{~kg}$ & $1230 \mathrm{~kg}$ \\
\hline Tüzelőanyag-mennyiség & 5301 & 7301 \\
\hline Felszállótömeg & $1950 \mathrm{~kg}$ & $2300 \mathrm{~kg}$ \\
\hline \multicolumn{3}{|c|}{ Teljesítményadatok } \\
\hline Utazósebesség & $230 \mathrm{~km} / \mathrm{h}$ & $240 \mathrm{~km} / \mathrm{h}$ \\
\hline Függőleges emelkedési sebesség & $8 \mathrm{~m} / \mathrm{s}$ & \\
\hline Hatótávolság & $700 \mathrm{~km}$ & 850 km \\
\hline Szolgálati csúcsmagasság & $5,6 \mathrm{~km}$ & $4 \mathrm{~km}$ \\
\hline \multicolumn{3}{|c|}{ Hajtómú jellemzők } \\
\hline Fajtája & \multicolumn{2}{|c|}{$\begin{array}{c}\text { tengelyteljesítményt szolgáltató } \\
\text { gázturbina }\end{array}$} \\
\hline Típusa & $\begin{array}{c}\text { Turbomeca } \\
\text { Arriel vagy Avro } \\
\text { Lycoming } \\
\text { LTS101-600A2 }\end{array}$ & $\begin{array}{c}\text { Allison } \\
250-C 20 F\end{array}$ \\
\hline Száma & 1 & 2 \\
\hline Teljesítménye & $\begin{array}{l}478 \mathrm{~kW} \text { (650LE) } \\
457 \mathrm{~kW} \text { (622LE) }\end{array}$ & $\begin{array}{c}2 \times 317 \mathrm{~kW} \\
(863 \mathrm{LE})\end{array}$ \\
\hline \multicolumn{3}{|c|}{ Fülkeméretek } \\
\hline Hosszúság & \multicolumn{2}{|c|}{$2,42 \mathrm{~m}$} \\
\hline Szélesség & \multicolumn{2}{|c|}{$1,65 \mathrm{~m}$} \\
\hline Magasság & \multicolumn{2}{|c|}{$1,35 \mathrm{~m}$} \\
\hline Személyzet & \multicolumn{2}{|c|}{1 fö } \\
\hline Rendszerbe állítás éve & 1978 & 1982 \\
\hline
\end{tabular}


